\title{
A spatial analysis model to assess the feasibility of short rotation forestry fertigated with urban wastewater: Basilicata region case study
}

\author{
Mario Cozzi ${ }^{\mathrm{a}, *}$, Mauro Viccaro ${ }^{\mathrm{a}}$, Francesco Di Napoli ${ }^{\mathrm{a}}$, Claudio Fagarazzi ${ }^{\mathrm{b}}$, \\ Alessandro Tirinnanzi ${ }^{\mathrm{b}}$, Severino Romano ${ }^{\text {a }}$ \\ a School of Agricultural, Forestry, Food and Environmental Sciences - SAFE, University of Basilicata, 85100 Potenza, Italy \\ ${ }^{\mathrm{b}}$ Department of Agricultural, Food and Forest Systems Management, University of Florence, P.le delle Cascine 18, I-50144 Florence, Italy
}

\section{A R T I C L E I N F O}

\section{Article history:}

Received 12 June 2014

Received in revised form 10 June 2015

Accepted 12 June 2015

Available online 26 June 2015

\section{Keywords:}

Spatial multi-criteria evaluation

Land suitability

Vegetation filter systems

Irrigation water requirements

Green economy

Economic benefits

\begin{abstract}
A B S T R A C T
The large-scale cultivation of energy crops irrigated with non-conventional water resources could reduce the negative impacts of fossil fuel use, while still saving potable supplies and decreasing pollution in surface water, particularly in water-deficient environments, like the Mediterranean region. Energy planning is a complex process involving multiple decision makers and criteria. Given the spatial nature of the problem, the research proposes a spatial analysis model to assess the agronomic and economic feasibility of vegetation filter systems in Basilicata region, southern Italy. The model chosen for land suitability analysis is the ordered weighted averaging (OWA) with the use of linguistic quantifiers. The suitability map obtained from the OWA model was used as input in the spatial analysis functions to quantify the productivity and irrigation needs of the species, the potential irrigable service area of the wastewater treatment plants (WWTPs), as well as the distances between them and SRF, which are all key elements in the economic evaluation. The results show that the distance is the main element that influences the feasibility: only 25 out of 163 WWTPs are cost-effective and can actually irrigate 864 ha of SRF. The research demonstrates that there is a great potential for bio-energy development in the region with significant economic advantages; in fact, there is a large number of sites with positive NPV up to $50,876.43 € /$ ha and payback period between 3 and 10 years. The implementation of vegetation filter systems could create chains with a high number of local actors (farmers, intermediaries, forest nurseries, etc.) and contribute to promoting territorial development and employment.
\end{abstract}

(c) 2015 Elsevier B.V. All rights reserved.

\section{Introduction}

Bioenergy has a significant potential to mitigate greenhouse gases (GHGs), provided that sustainable strategies are adopted to develop resources, and efficient bioenergy systems are used (Styles and Jones, 2007; IPCC, 2011). Considered as the most promising renewable resource in the short and medium term (Hoogwijk et al., 2003), bioenergy is expected to play an increasing role in Europe, in view of achieving the targets recently established by the European Union on energy supply security and in compliance with international agreements on emission reductions. Within this context

\footnotetext{
* Corresponding author. Fax: +39 0971205409.

E-mail addresses: mario.cozzi@unibas.it (M. Cozzi), mauro.viccaro@unibas.it (M. Viccaro), francesco.dinapoli@unibas.it (F. Di Napoli), severino.romano@unibas.it (S. Romano).
}

the biomass produced on agricultural soils will play an important role (Bernetti et al., 2004; EEA, 2013), related in particular to shortrotation forestry (SRF) (Dornburg et al., 2008, 2010; Romano et al., 2013a,b). Actually, following the IPCC report on renewable energies (IPCC, 2011), it would be possible to obtain up to $700 \mathrm{EJ} /$ year from dedicated biomass crops grown on abandoned lands and/or on soils not planted with food crops. In the Basilicata Region, southern Italy, marginal farmland areas are being increasingly abandoned due to their low productivity in terms of output and product type, and as a result of the major reforms of the EU Common Agricultural Policy (Romano and Cozzi, 2008). It follows that there is a large availability of soils suitable for bioenergy crops, but there is still a need to convince farmers of the cost effectiveness of growing bioenergy crops. Several studies show that the gross margin for SRF cultivation is positive only if biomass production is $>9 \mathrm{tDM} / \mathrm{ha} \times$ year (Rosenqvist and Dawson, 2005a; Dimitriou and Rosenqvist, 2011; IEA Bioenergy, 2011). In Italy the yield values of SRF vary from 
North-South, mostly as related to the existing precipitation levels; surveys conducted in southern Italy (Bergante et al., 2013) report yield levels ranging between 5.6 and $6.1 \mathrm{tDM} / \mathrm{ha} \times$ year, respectively, for poplar and willow, against values ranged between 7-10 and 14-16 tDM/ha $\times$ year for poplar and willow in northern Italy (Bergante and Facciotto, 2006; Facciotto et al., 2012). Irrigation and the application of fertilizers become, thus, necessary to achieve high productivity levels, especially in Mediterranean environments, characterized by water deficits notably in summer (Barbera et al., 2009). In those environments, the use of unconventional water resources is an excellent strategy to reduce the use of fresh water resources in agriculture while still supplying crops with water and nutrients (FAO, 2010); actually the European Union is stimulating and encouraging the spread of such a practice (European Commission, 2012).

The implementation of multifunctional SRF plantations has, thus, become a sound alternative to conventional SRF for the considerable economic and environmental benefits associated with them (Rosenqvist and Dawson, 2005b; Berndes et al., 2008; Ericsson et al., 2009; Dimitriou and Rosenqvist, 2011). These plantations, irrigated with wastewater and consisting of species such as willows (Salix spp.) and poplars (Populus spp.), are defined “vegetation filter systems" and are intended for the production of energy biomasses and phytoremediation (Guidi et al., 2008). Wastewater supplies plants with water and nutrients, notably nitrogen and phosphorus, thus favouring crop growth; the plants, characterised by high transpiration rates, clean water by uptaking the dissolved elements, including heavy metals (e.g., cadmium) (BIOPROS, 2008).

Despite the many economic and environmental benefits proved by experimentation conducted in North-Central Europe countries (Rosenqvist and Dawson, 2005a,b; Börjesson and Berndes, 2006; BIOPROS, 2008; Dimitroiu and Aronsson, 2011; Dimitriou and Rosenqvist, 2011; Holm and Heinsoo, 2013) and although the Italian legislation allows the use of wastewater in agriculture 1 , the applications in Italy of multifunctional SRF for the production of biomasses and water purification are limited (BIOPROS, 2008; Guidi et al., 2008).

This work has as its main objective the development and application of a GIS-based spatial analysis model aimed at identifying areas potentially suitable for creating vegetation filter systems. Based on the existing wastewater treatment plants (WWTPs) in a given area, the use of a large scale land analysis model would enable public and private decision-makers to make targeted investments (Cozzi et al., 2013). The above model has been applied to the Basilicata region, characterized by a typically Mediterranean climate with summer water deficits that justify the use of unconventional water resources for irrigation for not undermining drinking water supply in urban areas. The idea stems from the research conducted at the University of Basilicata that has developed a system for urban wastewater treatment based on "conventional activated sludge"; this system enables the production of water with a varying load of organic carbon, nitrogen and phosphorus, so as to adapt water to the needs of irrigated crops, thus reducing the treatment costs by about 20-30\% (Lopez et al., 2006; Masi et al., 2008).

The whole model has been designed to focus not only on environmental sustainability (proper use of wastewater, exclusion of nitrate-vulnerable zones) but also on the cost effectiveness of growing SRF fertigated with urban wastewater, all core potential elements for the spreading of these systems.

\section{Potentials of vegetation filter systems}

Most studies on vegetation filter systems have focused on their environmental and economic impacts and have shown that they are viable only if the use and management of urban wastewater is safe for the environment (minimum leaching of nutrients in ground water), if the purification efficiency of these systems is equal to that of other treatment methods and if it is allowed by the national legislation (Dimitriou and Rosenqvist, 2011). It has been demonstrated that the treatment efficiency may be even higher than that of conventional treatments (Hasselgren, 2003), with retention up to 96\% for nitrogen and 94\% for phosphorus (Dimitroiu and Aronsson, 2011), whereas leaching processes depend on the load of nutrients contained in wastewater more than on irrigation flow rates (Dimitroiu and Aronsson, 2004; Rosenqvist and Dawson, 2005b). Hence, the pretreatment of water (Aronsson, 2000; Carlander and Stenström, 2001) and the calculation of crop irrigation requirements (Guidi et al., 2008) can ensure high efficiency of these water treatment systems without any risk for the environment. At the same time, the application of water rich in nutrients results in a substantial increase of crop yields. If $100 \%$ yield increases have been recorded in north Europe countries (Börjesson and Berndes, 2006), more sustained increases have been observed in Mediterranean environments. In a study conducted in Italy, yield values are reported to increase from 6.6 to about $64 \mathrm{tDM} /$ ha for willow and from about 9 to $44.4 \mathrm{tDM} /$ ha for poplar, when crops are irrigated with wastewater (Guidi et al., 2008). These results are due to the higher evapotranspiration rate observed in arid climates, where large volumes of wastewater may be actually treated. This produces economic benefits both for farmers who can rely on higher returns related to higher crop yields and a 25-30\% cut of production costs, and for the companies working in urban wastewater treatment that can largely reduce purification costsby using the vegetation filter systems as an alternative to conventional treatments (Rosenqvist and Dawson, 2005b; Börjesson and Berndes, 2006; Dimitriou and Rosenqvist, 2011).

Despite the many experiences, which prove the considerable economic and environmental benefits, the spread of SRF fertigated with wastewater is limited. Different literature studies have proposed GIS-based land use suitability models for identifying the most potentially suitable soils for SRF (Salvati et al., 2007; Romano et al., 2013a), but none of them has produced a model specifically targeted to identify the WWTPs that can be used for the fertigation of those soils. The use of this large scale analysis model would facilitate public and/or private decision-making for the establishment and spreading of vegetation filter systems.

For building the spatial analysis model wholly developed using GIS, this work has focused on the following practical aspects that impact directly on the real potential of vegetation filter systems (BIOPROS, 2008; Guidi et al., 2008):

1. Use of urban wastewater for fertigation in agriculture allowed by law.

2. Land suitability for SRF plantations.

3. Local availability of urban wastewater.

4. Short distances of treatment plants from SRF plantations, so as to reduce the investment costs of the conveyance pipeline.

5. Benefits resulting from multifunctional SRF plantations for farmers, society and the environment.

An additional economic aspect needs to be taken into account to minimize the investment costs of fertigation system: SRF planted areas should be located downstream of treatment plants to reduce water pumping costs.

The Italian legislation (see footnote 1) allows for the reuse of wastewater in agriculture, provided that the legal limits are complied with; in this work wastewater is assumed to be pretreated by the "conventional activated sludge" systemto make it compliant with legal limits and to meet crop requirements. 
Land suitability was assessed using a multicriteria geographical analysis model that was used to identify exactly the areas destined for SRF plantations with poplars and willows (see Section 3.1).

As for the availability of water to be used for fertigation, the first step was to calculate the potential irrigable service area of WWTPs, meant as the area of land that can be irrigated with the effluent of each WWTP. This required the calculation of the irrigation water requirement (IWR) for each crop under analysis (see Section 3.2).

The second step was to build the analysis model aimed to delimit the vegetation filter systems as a function of their distances from the WWTPs (see Section 3.3).

The model was supported by an economic analysis intended to assess the benefits resulting from these systems. This analysis resulted in the identification of the areas where investments are cost effective.

In this work, we considered the SRF plantation with a 12-year life cycle, biennial coppicing and plant density of 10,000 plants/ha.

\section{Materials and methods}

\subsection{Land Suitability}

The land suitability analysis for willow and poplar SRF plantations was conducted using a Multi-Criteria Evaluation (MCE) and Geographical Information Systems (GIS) approach. This integration may be conceived of as a process that combines and transforms spatial and non-spatial data (input) in a decision-making result (output), by defining a relation between input maps and output maps as influenced by geographical data and decision preferences, handled following specific combination rules (Malczewski, 2004; Bernetti et al., 2011).

The multi-criteria evaluation methods applied for GIS-based land use suitability analysis are overlay Boolean operations, Weighted Linear Combination (WLC) and Ordered Weighted Averaging (OWA) methods (Heywood et al., 1995; Jankowski, 1995; Barredo, 1996; Beedasy and Whyatt, 1999; Malczewski, 2004; Romano and Cozzi, 2006; Romano et al., 2013a).

The method applied in this work is the OWA operator combined with relative linguistic quantifiers, as proposed by Romano et al. (2013a). The choice of this method is justified by its greater flexibility as compared to MCE methods: actually a linguistic quantifier can better represent the decision maker's qualitative information than its perceived relation between different evaluation criteria, notably when a high number of maps are involved in the analysis.
Table 1

Some RIM (Regular Increasing Monotone) linguistic quantifiers and their properties.

\begin{tabular}{lll}
\hline$\alpha$ & RIM quantifier & ORness \\
\hline$\alpha \rightarrow 0$ & At least one & 1.0 \\
$\alpha=0.1$ & At least a few & $*$ \\
$\alpha=0.5$ & A few & $*$ \\
$\alpha=1$ & Half (identity) & 0.5 \\
$\alpha=2$ & Most & $*$ \\
$\alpha=10$ & Almost all & $*$ \\
$\alpha \rightarrow \infty$ & All & 0.0 \\
\hline
\end{tabular}

Given a set of criterion maps standardized by fuzzy functions $[0,1]$ (Zadeh, 1965), the method involves the calculation of two series of weights: criterion weights and order weights. While the former are calculated using the AHP (Analytical Hierarchy Process) method (Saaty, 1980), order weights are determined by the following equation:

$v_{j}=\left(\Sigma_{k=1}^{i} u_{\mathrm{k}}\right)^{\mathrm{a}}-\left(\Sigma_{k=1}^{j-1} u_{\mathrm{k}}\right)^{\mathrm{a}}$

where $v_{j}$ is the criterion weight rearranged based on the value of the criterion map ( $j$ ), for $j=1,2, \ldots, n$, and $\alpha$ is the parameter associated with the RIM (Regular Increasing Monotone) linguistic quantifier (Yager, 1996; Malczewski, 2006) (Table 1). It results that for determining order weights it is important to arrange in a decreasing order criterion maps standardized based on their value, so as to rearrange associated criterion weights and choose the appropriate linguistic quantifier that best describes decision makers' preferences.

The criterion maps and fuzzy functions used in the analysis are those proposed by Romano et al. (2013a). The maps arranged according to their value and the value of calculated weights are shown in Table 2.

As for the choice of the linguistic quantifier that has allowed for the calculation of order weights, some remarks have been made. The success of an SRF plantation depends on two conditions: (i) that the species finds the optimal soil and climate conditions (notably water and nutrient supply) and (ii) the plantation management might be based on crop requirements (mechanization, irrigation). Therefore, it is evident that the higher the number of criteria included in the analysis, the more real the result. The linguistic quantifiers that best express this concept are: All, Almost all and Most, which are associated with a low degree of ORness (Malczewski, 2006), namely, the degree of risk associated with the analysis.

Table 2

Criterion and weights used in Ordered Weighted Averaging analysis.

\begin{tabular}{|c|c|c|c|c|}
\hline Species & Criterion map (j) & Ordered criterion values & Reordered criterion weights uj & Ordered weights vj \\
\hline \multirow[t]{10}{*}{ Populus spp. } & Elevation & 0.9430 & 0.0242 & 0.1556 \\
\hline & Soil depth & 0.9340 & 0.1646 & 0.2789 \\
\hline & Mean temperature in the coldest month & 0.8390 & 0.0354 & 0.0390 \\
\hline & Soil reaction & 0.7820 & 0.1143 & 0.1083 \\
\hline & Mean annual temperature & 0.7780 & 0.0354 & 0.0297 \\
\hline & Carbonates & 0.4990 & 0.2381 & 0.1708 \\
\hline & Soil texture & 0.4550 & 0.2381 & 0.1397 \\
\hline & Average annual precipitation & 0.4490 & 0.0534 & 0.0285 \\
\hline & Slope & 0.3300 & 0.0178 & 0.0093 \\
\hline & Average precipitation in summer months & 0.0200 & 0.0787 & 0.0402 \\
\hline \multirow[t]{10}{*}{ Salix spp. } & Elevation & 0.9630 & 0.0221 & 0.1487 \\
\hline & Soil depth & 0.9340 & 0.0449 & 0.1102 \\
\hline & Soil texture & 0.6570 & 0.0671 & 0.1074 \\
\hline & Carbonates & 0.4990 & 0.0311 & 0.0403 \\
\hline & Mean temperature in the coldest month & 0.4830 & 0.1476 & 0.1528 \\
\hline & Mean annual temperature & 0.4490 & 0.1013 & 0.0842 \\
\hline & Slope & 0.3300 & 0.0166 & 0.0128 \\
\hline & Soil reaction & 0.2960 & 0.0671 & 0.0493 \\
\hline & Average annual precipitation & 0.1650 & 0.2101 & 0.1358 \\
\hline & Average precipitation in summer months & 0.0200 & 0.2921 & 0.1586 \\
\hline
\end{tabular}


If this is true in the traditional management of SRF, where only supplemental irrigation is applied, in the specific case, we contribute to the success of the crop by using wastewater - submitted to simplified treatment - that is rich in organic matter and nutrients available all the year round. Based on the above, a greater risk may be reasonably accepted in the evaluation process; for this reason the linguistic quantifier "A few" has been preferred for determining order weights that will result in a more optimistic analysis scenario than those generated by previously mentioned quantifiers.

It is noteworthy that the analysis excluded the soils whose land suitability did not allow SRF, such as artificial areas, permanent crops, wooded areas, wetlands and water bodies.

\subsection{Irrigation requirements and productivity}

In order to estimate the area of land that can be irrigated with the effluent of each WWTP, a thorough analysis of the irrigation water requirements of each crop was performed.

Irrigation water requirement (IWR) is the amount of water that has to be applied in addition to rainfall to serve crop water requirements. For irrigation planning, it is determined as the difference between crop evapotranspiration $\left(\mathrm{ET}_{\mathrm{C}}\right)$ and that part of rainfall which is effectively used by plants (Pe) (FAO, 1986):

$\mathrm{IWR}=\mathrm{ET}_{\mathrm{c}}-\mathrm{Pe}$

The $\mathrm{ET}_{\mathrm{c}}$ is calculated by multiplying the reference crop evapotranspiration $\left(\mathrm{ET}_{0}\right)$ by a crop coefficient $\left(K_{\mathrm{c}}\right)(\mathrm{FAO}, 1998)$ :

$\mathrm{ET}_{\mathrm{c}}=\mathrm{ET}_{0} \times K_{\mathrm{c}}$

In the case of vegetation filter, $\mathrm{ET}_{\mathrm{c}}$ also represents the maximum amount of wastewater that can be supplied to the plantation reducing environmental risks of pollution from nutrient leaching to the groundwater (Pistocchi et al., 2009).

In the present study, considering SRF with biennial coppicing, the monthly $\mathrm{ET}_{\mathrm{c}}(\mathrm{mm})$ was calculated for both growing seasons, using raster images representing the monthly $\mathrm{ET}_{0}(\mathrm{~mm})$ and the $K_{\mathrm{c}}$ values of tested crops, already calculated in a work conducted on vegetation filters in Mediterranean environments (Guidi et al., 2008).

Effective rainfall was calculated by the formula proposed by the Soil Conservation Service of the United States Department of Agriculture (USDA, 1993), adjusted for units converted from inches to $\mathrm{mm}$ :

$\mathrm{Pe}=f_{\mathrm{c}}\left(1 \cdot 253 \times P^{0.824}-2 \cdot 935\right) \times 10^{0.001 \mathrm{ET}_{\mathrm{c}}}$

where $f_{\mathrm{c}}$ is the correction factor depending on the soil available moisture; for the present work it is assumed to equal 1 (standard soil condition); $P$, total monthly rainfall.

In this way, the monthly and seasonal IWR values were calculated for both growing seasons (two-year cropping cycle) and subsequently converted to cubic meters.

The biomass productivity was calculated from the water-use efficiency of productivity (WUE) (Fischer et al., 2011). The WUE was obtained by dividing the biomass produced, expressed as organic dry matter, by the water lost by transpiration or whole evapotranspiration (de Wit, 1958; Lindroth et al., 1994; Cienciala and Lindroth, 1995; Linderson et al., 2007; Forrester et al., 2010; Fischer et al., 2011). Vice versa, by multiplying the WUE (expressed in grams of dry biomass per kilo of water lost by evapotranspiration) by the seasonal $\mathrm{ET}_{\mathrm{c}}$ you determine the potential production of annual dry biomass.

For the sake of consistency in the estimates, the WUE was determined from Guidi et al. (2008) and was equal to 2.14 and $2.4 \mathrm{~g}$ of dry biomass per kg of water lost by evapotranspiration, respectively for willows and poplars. Considering the biomass produced in two growing seasons, we obtained the raster of two-year productivities expressed in tons of dry matter, subsequently converted to tons of fresh matter, assuming roadside sale of wood chips. The estimated productivities were very high, averaging $73 \mathrm{tDM} /$ ha in the two-year period, nearly the double as compared to the yields obtained by Guidi et al. (2008). This is due to higher evapotranspiration rates than those recorded in the specific environments and under the tested conditions.

\subsection{Spatial model analysis}

A Geographic Information System (GIS) may be defined as the complex system including hardware, software, human and intellectual resources used to collect, process, analyze, store and return - in a graphic and alphanumeric form - the data concerning a territory (ENEA, 2006). GIS software makes use of a set of spatial analysis tools useful to create, query, map and analyze cell-based raster data, perform integrated raster/vector analysis, derive new information from existing data, query information across multiple data layers and fully integrate cell-based raster data with traditional vector data source (ESRI, 2001). A GIS model generally returns output as derivatives of base maps, and can comprise whole hierarchical trees of data and functions. A GIS model is built up from data and handling software.

In the model applied in the present work (Fig. 1), the input geographic database is made up of a set of maps characterizing the land area and includes information concerning the criterion variables useful for the analysis (Fig. 2).

The database of WWTPs consists of an attribute table containing information about the identification number, the monthly and seasonal flow rate $\left(\mathrm{m}^{3}\right)$, and the elevation. Where relevant, the vector data has been converted to raster images for the execution of spatial analysis functions. The raster regarding land rent (the income derived from each plot with the existing crop) reports the values per hectare of arable lands, meadows and rangelands for different agricultural regions. The area under study covers the whole Basilicata regional territory, represented through a reference grid resolution of $100 \mathrm{~m}$, using Gauss Boaga East on Monte Mario Roma 1940 Datum as geographical reference system. The choice of this spatial resolution is related to a merely practical aspect: the area of each pixel, equal to one hectare, is the optimal reference unit for the analysis in question.

The spatial analysis functions applied in this work, which are common to most commercial GIS software, are summarized in Table 3.

As shown in Fig. 1, the development of the model has followed a logical path, based on which there is the raster relating the areas of influence of WWTPs. Identified from the map of plant localization through the distance allocation function, each of them was assigned the identification number of the relevant treatment plant, so that any information collected within each area may be easily associated with it.

For determining the potential irrigable service area of WWTPs, given by the ratio of the flow rate $\left(\mathrm{m}^{3}\right)$ to the seasonal $\operatorname{IWR}\left(\mathrm{m}^{3} / \mathrm{ha}\right)$, the raster relating the second growing season irrigation requirement was taken. This choice is based on the consideration that the potential irrigable service area should be calculated on the maximum IWR, which occurs exactly in the second year as a result of higher evapotranspiration rates.

\subsection{Economic analysis}

The possibility to use agricultural land to create vegetation filter systems depends on the cost effectiveness of these systems. To that purpose, some economic indicators were calculated that are a reference point for farmers in alternative investments. 

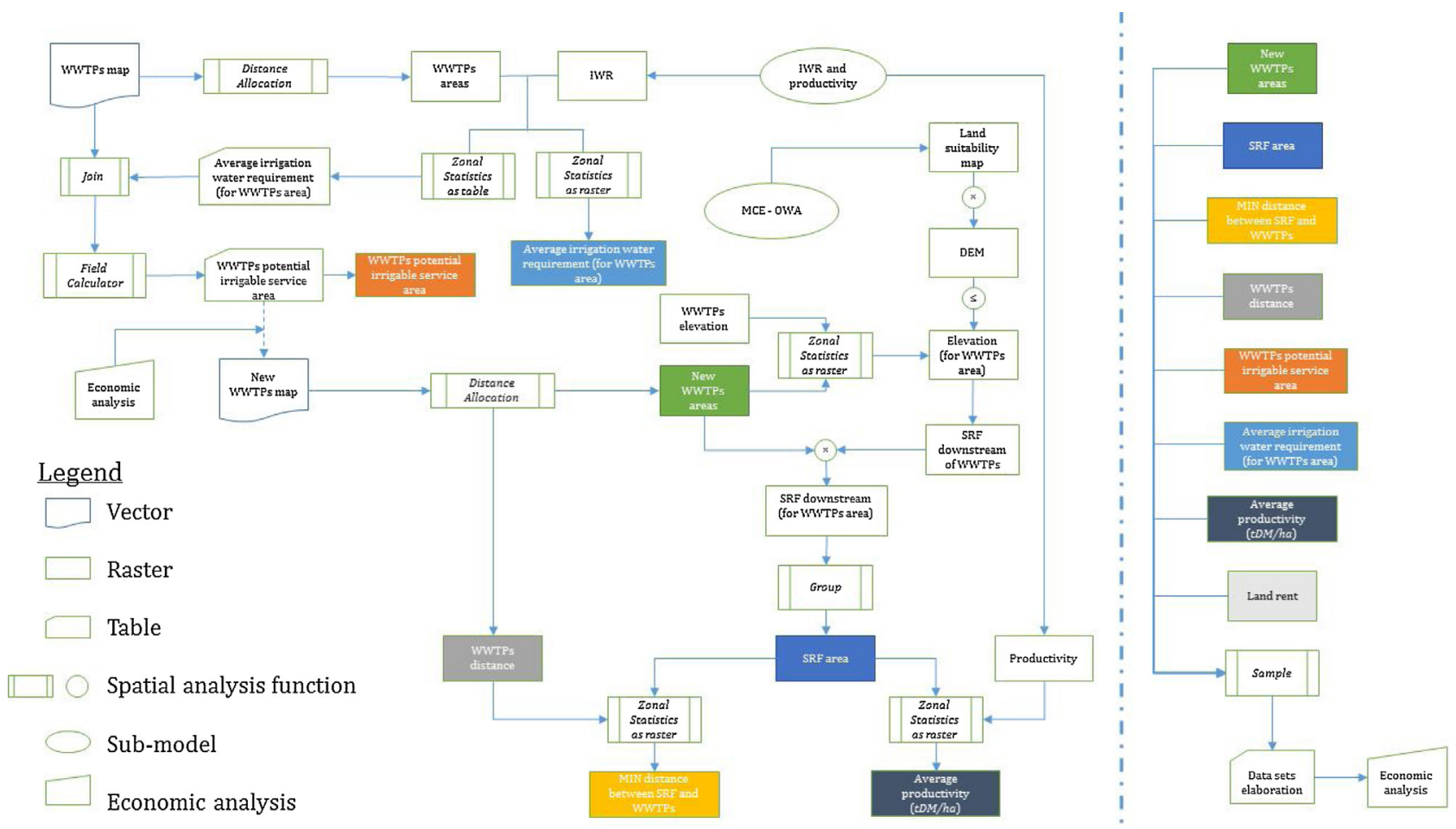

Fig. 1. Hierarchical tree of spatial analysis model.

Table 3

Spatial analysis function.

\begin{tabular}{|c|c|}
\hline Function & Description \\
\hline Distance allocation & $\begin{array}{l}\text { Performs spatial allocation using either distance } \\
\text { surfaces, calculating the distance/proximity of each pixel } \\
\text { to the nearest of a set of target pixels or points }\end{array}$ \\
\hline Zonal statistic & $\begin{array}{l}\text { Summarizes the values of a raster within the zones of } \\
\text { another dataset (either raster or vector) and reports the } \\
\text { results as a table or a raster }\end{array}$ \\
\hline Join & $\begin{array}{l}\text { Joins the item definitions and values of two tables based } \\
\text { on a shared item }\end{array}$ \\
\hline Field calculator & $\begin{array}{l}\text { Allows performing calculations on the basis of existing } \\
\text { attribute values or defined functions }\end{array}$ \\
\hline Map calculator & $\begin{array}{l}\text { Enables solving complex spatial problems, working with } \\
\text { raster, through the use of mathematical and logical } \\
\text { expressions }\end{array}$ \\
\hline Group & $\begin{array}{l}\text { Classifies pixels according to contiguous groups. For each } \\
\text { cell in the output, the identity of the connected group to } \\
\text { which that cell belongs is recorded. A unique number is } \\
\text { assigned to each group }\end{array}$ \\
\hline Sample & $\begin{array}{l}\text { Creates a table that shows the values of cells from a } \\
\text { raster, or set of rasters, for defined locations. The } \\
\text { locations are defined by raster cells or by a set of points }\end{array}$ \\
\hline
\end{tabular}

More specifically, the analysis concerned the calculation of the Net Present Value (NPV) and the Payback Period (PBP) of the areas planted with SRF fertigated with wastewater:

$\mathrm{NPV}=\Sigma_{k=0}^{n} \frac{\mathrm{FC}_{k}}{(1+r)^{k}}$

$\mathrm{FC}_{k}$ : flux at year $k$ obtained from the benefits at year $k$ minus the costs at year $k$;

$k$ : project length in years;

$r$ : cost of capital.

$\mathrm{PBP}=\frac{\text { InIv }}{\text { ChIFP }}$

InIv = Initial Investment.

ChIFP $=$ Cash Inflow per Period.
Table 4

Cropping management costs of Short Rotation Forestry.

\begin{tabular}{llll}
\hline Operations & Costs & Measurement unit & Year \\
\hline Plowing & 200 & $€ /$ ha & 0 \\
Rotary tillage & 70 & $€ /$ ha & 0 \\
Coppicing & 4300 & $€ /$ ha & 0 \\
Transplanting & 4300 & $€ /$ ha & 0 \\
$\begin{array}{l}\text { Chemical weed } \\
\quad \text { control }\end{array}$ & 100 & $€ /$ ha & I, III, V, VII, IX, XI \\
Harrowing & 120 & $€ /$ ha & I, III, V, VII, IX, XI \\
$\quad$ between rows & & & \\
Chipping & 20 & $€ /$ tonn (fresh matter) & II, IV, VI, VIII X, XII \\
Eradication & 8400 & $€ /$ ha & XII \\
$\begin{array}{l}\text { Setting up of } \\
\quad \text { irrigation system }\end{array}$ & 2000 & $€ /$ ha & 0 \\
\hline
\end{tabular}

The NPV expresses the increase in wealth generated by the project as compared with the existing situation, expressed as if it were immediately available at the start of the conversion (Bernetti et al., 2004; Ciccarrella and Carbone, 2006); the PBP is the time in which the initial cash outflow of an investment is expected to be recovered from the cash inflows generated by the investment.

The logical procedure followed for the evaluation involved the determination of the costs (investment and running costs) and benefits (revenue generated by the investment) produced by the areas planted with SRF and the setting up of the fertigation system.

The length of the production cycle is estimated to be 12 years with biennial coppicing and plant density of $10.000 \mathrm{pha}^{-1}$. The costs for the setting up, management and restoration of the land (Table 4) are calculated on the basis of market prices of farm inputs, as well as the experimental trials conducted (Spinelli et al., 2006; ENAMA, 2008; F.I.M.A.V, 2012). Moreover, the discount rate was estimated to $4.5 \%$. It was obtained on the basis of the return of ten-year Italian Treasury Bonds (Index-linked BTPs) (Banca d'Italia, 2013). As to the land rent, its value is contained in the geographic database (see Section 3.2).

The benefits associated with the investment derive, however, from the sale of chips; they have been obtained by multiplying bien- 


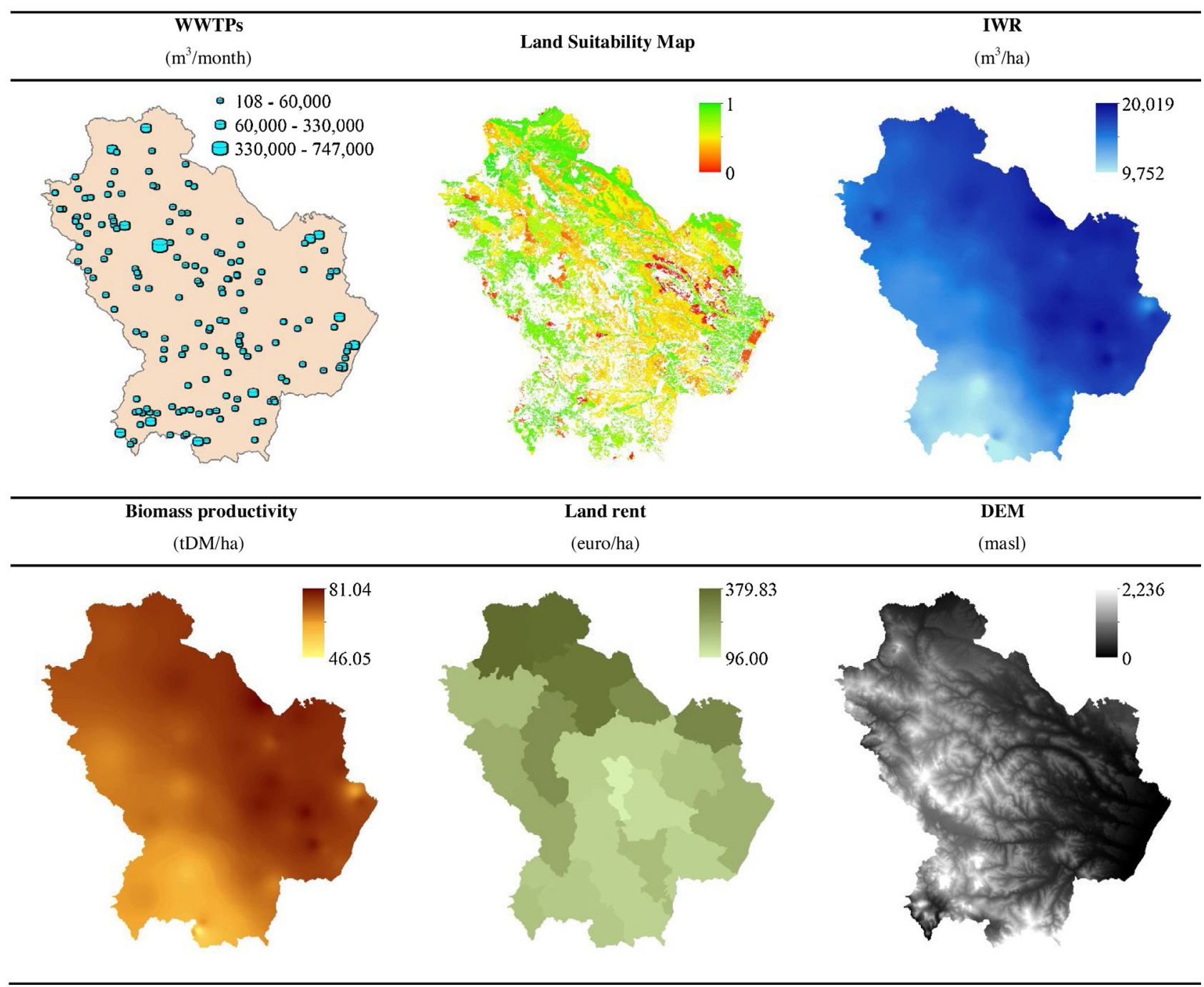

Fig. 2. Input data.

Table 5

Costs for the setting up of fertigation system.

\begin{tabular}{lll}
\hline Components of fertigation system & Measurement unit & Costs \\
\hline Conveyance pipe & $€ / \mathrm{m}$ & 200 \\
Storage tank & $€$ & 50,000 \\
Pumps, filters & $€$ & 50,000 \\
\hline
\end{tabular}

nial production (see Section 3.2) by the selling price of fresh matter ( $50 \%$ WC) that amounts to $€ 55 / t$ at roadside. The latter value has been deduced from measurements taken in plants already working in the Basilicata region (Southern Italy). This data is in agreement with what is reported by Fiala (2012), where the mean price is estimated to $€ 55-60 / t$ untreated, for good quality wood chips.

However, among benefit items the possible revenues generated in the form of white certificates that would lead to extra economic profits were not considered (Romano et al., 2013b; Cozzi et al., 2014).

Fertigation system costs include the installed water conveyance pipe from the WWTP to the SRF areas, the storage tank, as well as the pumps and filters required for the distribution and pre-treatment of water. The cost items (AA.VV., 2012) are shown in Table 5.

Since the alternative treatment of wastewater through vegetation filter systems results in an economic advantage for the companies in charge of water treatment, a further increase of vegetation filter productivity for farmers could derive from the economic compensation they would have when accepting that water in their soils. A study conducted in Ireland has demonstrated that this compensation may amount to 788-2004 GBP/ha year (Rosenqvist and Dawson, 2005b). The exact amount of the compensation is difficult to define or predict, as it depends on the agreements between wastewater treatment plant operators and the farmers concerned, on the water volumes and the costs of other treatment methods. In the specific case study, following estimates carried out after wastewater treatment by the conventional activated sludge process (see Section 1), the amount of compensation is considered to be $0.19 € / \mathrm{m}^{3}$ of water used in fertigation.

\section{Results}

The multicriteria analysis model has resulted in the suitability maps of SRF for willows and poplars (Fig. 3). Based on the distribution of suitability values, poplar seems to be the species with the highest suitability for SRF in the region (Romano et al., 2013a). This confirms the findings of recent studies showing that willow is a more suitable species under the typical site-specific conditions of north-Europe countries (Dimitriou and Rosenqvist, 2011; IEA Bioenergy, 2011).

To facilitate the reading of the results obtained using the OWA model, the values achieved have been discretized using Chen 


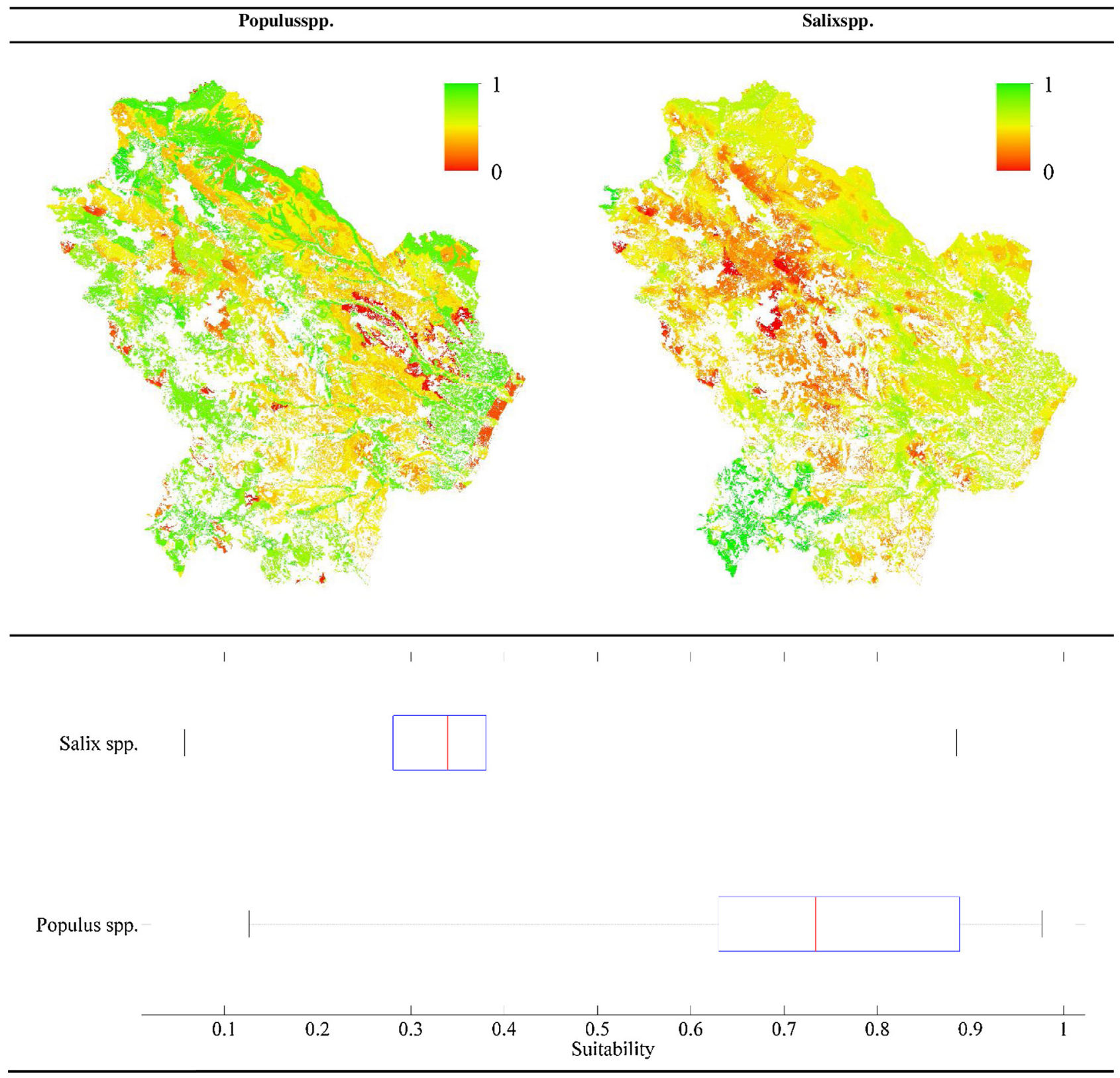

Fig. 3. Land suitability map and box-plot of suitability values.

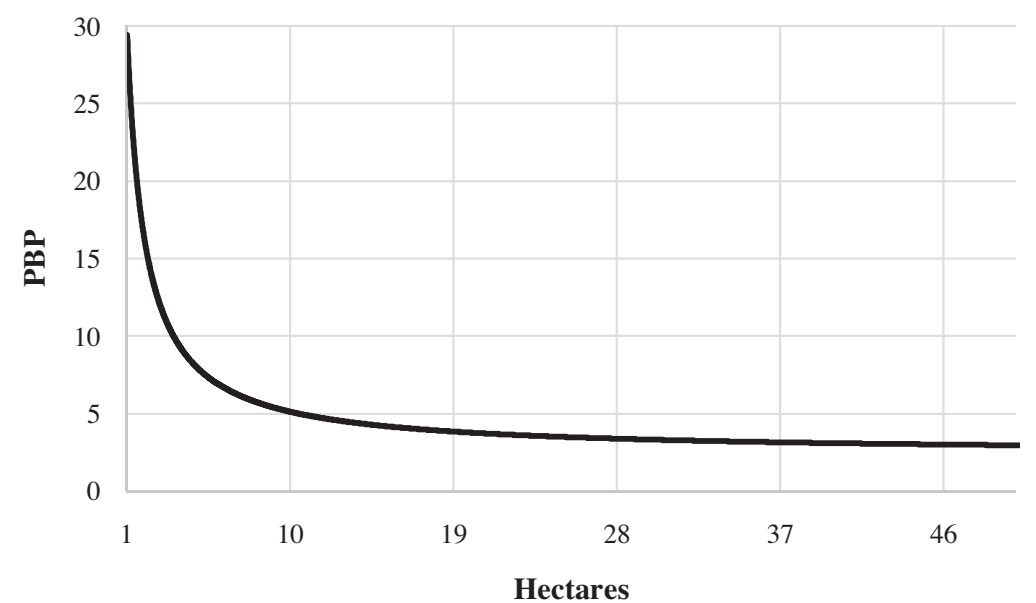

Fig. 4. Payback period for a SRF plantation sited at $100 \mathrm{~m}$ from the WWTP. 


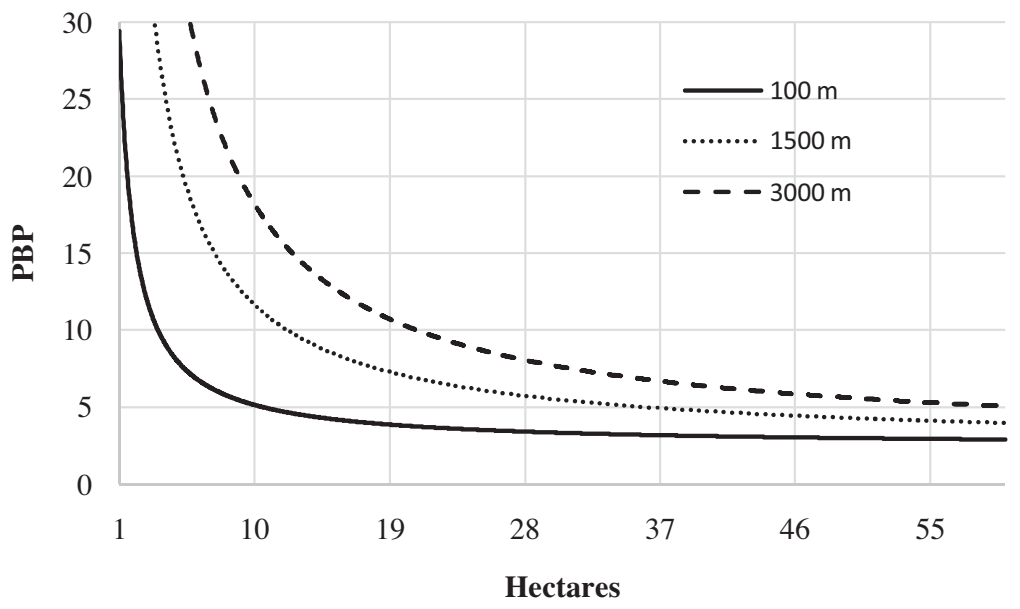

Fig. 5. Payback period calculated for an SRF plantation sited at distances of $100 \mathrm{~m}, 1500 \mathrm{~m}, 3000 \mathrm{~m}$.

Table 6

Sum-up table of cost effectiveness indicators for Short Rotation Forestry areas with positive Net Present Value, identified for each wastewater treatment plants.

\begin{tabular}{|c|c|c|c|c|c|c|c|c|}
\hline WWTPa & $\begin{array}{l}\text { Potential irrigable } \\
\text { service area }\end{array}$ & SRF Area & SRF surface & Distance & Irrigated surface & $\mathrm{NPV}^{\mathrm{a}}$ & NPV & $\mathrm{PBP}^{\mathrm{a}}$ \\
\hline $\mathrm{Id}^{\mathrm{a}}$ & ha $^{\mathrm{a}}$ & Id & ha & $\mathrm{m}^{\mathrm{a}}$ & ha & $€$ & $€ /$ ha & years \\
\hline \multirow[t]{5}{*}{7} & 13 & 379 & 113 & 2773 & 13 & 33800.73 & 2600.06 & 10 \\
\hline & 13 & 400 & 66 & 383 & 13 & 511790.62 & 39368.51 & 5 \\
\hline & 13 & 402 & 3454 & 1141 & 13 & 367431.91 & 28263.99 & 6 \\
\hline & 13 & 415 & 131 & 441 & 13 & 500074.89 & 38467.30 & 5 \\
\hline & 13 & 416 & 6 & 283 & 6 & 161135.69 & 26855.95 & 6 \\
\hline \multirow[t]{4}{*}{15} & 43 & 357 & 152 & 10083 & 43 & 81810.07 & 1902.56 & 10 \\
\hline & 43 & 464 & 90 & 8457 & 43 & 371906.87 & 8649 & 9 \\
\hline & 43 & 479 & 168 & 3638 & 43 & 1370682.89 & 31876.35 & 6 \\
\hline & 43 & 486 & 15 & 3080 & 15 & 50896.39 & 3393.09 & 10 \\
\hline 16 & 13 & 716 & 18 & 100 & 13 & 511752.00 & 39365.54 & 4 \\
\hline 22 & 11 & 468 & 5 & 566 & 5 & 43773.37 & 8754.67 & 9 \\
\hline 31 & 19 & 1672 & 10 & 566 & 10 & 167802.52 & 16780.25 & 7 \\
\hline \multirow[t]{2}{*}{39} & 11 & 1129 & 57 & 141 & 11 & 407720.57 & 37065.51 & 5 \\
\hline & 11 & 1148 & 6 & 941 & 6 & 4082.00 & 680.33 & 10 \\
\hline \multirow[t]{2}{*}{45} & 16 & 304 & 904 & 1190 & 16 & 502090.41 & 31380.65 & 6 \\
\hline & 16 & 346 & 270 & 2924 & 16 & 155227.52 & 9701.72 & 9 \\
\hline \multirow[t]{2}{*}{47} & 12 & 1542 & 507 & 1041 & 12 & 217390.40 & 18115.87 & 7 \\
\hline & 12 & 1557 & 8 & 200 & 8 & 210449.79 & 26306.22 & 6 \\
\hline \multirow[t]{3}{*}{59} & 17 & 1535 & 15 & 100 & 15 & 500207.39 & 33347.16 & 5 \\
\hline & 17 & 1544 & 169 & 2704 & 17 & 59613.57 & 3506.68 & 10 \\
\hline & 17 & 1549 & 29 & 2890 & 17 & 22456.38 & 1320.96 & 10 \\
\hline \multirow[t]{5}{*}{65} & 58 & 1622 & 74 & 4090 & 58 & 1438251.45 & 24797.44 & 6 \\
\hline & 58 & 1623 & 104 & 1500 & 58 & 1956241.33 & 33728.30 & 5 \\
\hline & 58 & 1632 & 41 & 100 & 41 & 1545618.87 & 37698.02 & 4 \\
\hline & 58 & 1635 & 107 & 1990 & 58 & 1849874.00 & 31894.38 & 5 \\
\hline & 58 & 1639 & 15 & 1207 & 15 & 267951.40 & 17863.43 & 7 \\
\hline \multirow[t]{3}{*}{68} & 10 & 1569 & 232 & 1290 & 10 & 47713.10 & 4771.31 & 10 \\
\hline & 10 & 1605 & 43 & 241 & 10 & 257418.75 & 25741.88 & 6 \\
\hline & 10 & 1621 & 44 & 1500 & 10 & 5703.02 & 570.30 & 10 \\
\hline \multirow[t]{3}{*}{70} & 17 & 1577 & 99 & 1166 & 17 & 336875.53 & 19816.21 & 7 \\
\hline & 17 & 1598 & 11 & 200 & 11 & 293537.57 & 26685.23 & 6 \\
\hline & 17 & 1600 & 4 & 100 & 4 & 37650.03 & 9412.51 & 9 \\
\hline \multirow[t]{4}{*}{74} & 38 & 1637 & 25 & 3556 & 25 & 213118.84 & 8524.75 & 9 \\
\hline & 38 & 1659 & 9 & 724 & 9 & 123875.69 & 13763.97 & 8 \\
\hline & 38 & 1670 & 84 & 2563 & 38 & 944305.31 & 24850.14 & 6 \\
\hline & 38 & 1681 & 37 & 6657 & 37 & 84512.85 & 2284.13 & 10 \\
\hline \multirow[t]{2}{*}{77} & 65 & 606 & 25 & 100 & 25 & 1271910.78 & 50876.43 & 3 \\
\hline & 65 & 645 & 21 & 1490 & 21 & 771215.15 & 36724.53 & 5 \\
\hline \multirow[t]{4}{*}{78} & 36 & 621 & 134 & 3000 & 36 & 1295438.01 & 35984.39 & 5 \\
\hline & 36 & 677 & 22 & 3446 & 22 & 430317.40 & 19559.88 & 7 \\
\hline & 36 & 707 & 32 & 3221 & 32 & 1029458.55 & 32170.58 & 6 \\
\hline & 36 & 762 & 20 & 4556 & 20 & 97449.74 & 4872.49 & 9 \\
\hline \multirow[t]{3}{*}{79} & 17 & 782 & 8 & 1231 & 8 & 92704.87 & 11588.11 & 8 \\
\hline & 17 & 789 & 51 & 3780 & 17 & 76850.67 & 4520.63 & 9 \\
\hline & 17 & 804 & 100 & 3111 & 17 & 224946.40 & 13232.14 & 8 \\
\hline \multirow[t]{2}{*}{81} & 38 & 40 & 72 & 7541 & 38 & 303690.84 & 7991.86 & 9 \\
\hline & 38 & 41 & 987 & 6043 & 38 & 606159.97 & 15951.58 & 8 \\
\hline
\end{tabular}


Table 6 (Continued)

\begin{tabular}{|c|c|c|c|c|c|c|c|c|}
\hline WWTPa & $\begin{array}{l}\text { Potential irrigable } \\
\text { service area }\end{array}$ & SRF $^{a}$ Area & SRF surface & Distance & Irrigated surface & $\mathrm{NPV}^{\mathrm{a}}$ & NPV & $\mathrm{PBP}^{\mathrm{a}}$ \\
\hline \multirow[t]{10}{*}{ Id $^{\mathrm{a}}$} & ha $^{\mathrm{a}}$ & Id & ha & $\mathrm{m}^{\mathrm{a}}$ & ha & $€$ & $€ /$ ha & years \\
\hline & 38 & 45 & 217 & 6607 & 38 & 490553.84 & 12909.31 & 8 \\
\hline & 38 & 46 & 488 & 5249 & 38 & 762269.46 & 20059.72 & 7 \\
\hline & 38 & 91 & 25 & 5080 & 25 & 141898.53 & 5675.94 & 9 \\
\hline & 38 & 101 & 27 & 3407 & 27 & 577087.30 & 21373.60 & 7 \\
\hline & 38 & 105 & 306 & 8083 & 38 & 198119.72 & 5213.68 & 9 \\
\hline & 38 & 115 & 59 & 5038 & 38 & 804279.59 & 21165.25 & 7 \\
\hline & 38 & 116 & 144 & 141 & 38 & 1783690.81 & 46939.23 & 3 \\
\hline & 38 & 127 & 240 & 6787 & 38 & 454573.96 & 11962.47 & 8 \\
\hline & 38 & 130 & 72 & 4321 & 38 & 947711.02 & 24939.76 & 6 \\
\hline \multirow[t]{3}{*}{101} & 11 & 145 & 26 & 2156 & 11 & 54794.15 & 4981.29 & 9 \\
\hline & 11 & 163 & 505 & 200 & 11 & 445921.15 & 40538.29 & 4 \\
\hline & 11 & 169 & 1145 & 541 & 11 & 377636.87 & 34330.62 & 5 \\
\hline \multirow[t]{3}{*}{104} & 23 & 713 & 33 & 2080 & 23 & 562607.05 & 24461.18 & 6 \\
\hline & 23 & 771 & 104 & 100 & 23 & 958586.89 & 41677.69 & 4 \\
\hline & 23 & 810 & 21 & 2373 & 21 & 410238.29 & 19535.16 & 7 \\
\hline \multirow[t]{8}{*}{112} & 302 & 597 & 95 & 10464 & 95 & 2518874.05 & 26514.46 & 6 \\
\hline & 302 & 614 & 135 & 11015 & 135 & 4392439.09 & 32536.59 & 5 \\
\hline & 302 & 639 & 85 & 13460 & 85 & 1423743.20 & 16749.92 & 8 \\
\hline & 302 & 644 & 141 & 11214 & 141 & 4650260.93 & 32980.57 & 5 \\
\hline & 302 & 674 & 50 & 11849 & 50 & 10118.65 & 202.37 & 10 \\
\hline & 302 & 675 & 783 & 18900 & 302 & 11619411.58 & 38474.87 & 5 \\
\hline & 302 & 715 & 81 & 100 & 81 & 3943154.23 & 48680.92 & 3 \\
\hline & 302 & 867 & 205 & 19227 & 205 & 6576721.67 & 32081.57 & 6 \\
\hline \multirow[t]{10}{*}{116} & 21 & 158 & 55 & 3707 & 21 & 218053.93 & 10383.52 & 9 \\
\hline & 21 & 164 & 23 & 4577 & 21 & 44084.12 & 2099.24 & 10 \\
\hline & 21 & 175 & 169 & 2690 & 21 & 421485.37 & 20070.73 & 7 \\
\hline & 21 & 183 & 17 & 2531 & 17 & 251396.28 & 14788.02 & 8 \\
\hline & 21 & 213 & 22 & 3600 & 21 & 239475.25 & 11403.58 & 8 \\
\hline & 21 & 218 & 12 & 1383 & 12 & 228845.86 & 19070.49 & 7 \\
\hline & 21 & 219 & 29 & 4000 & 21 & 159475.25 & 7594.06 & 9 \\
\hline & 21 & 225 & 16 & 1800 & 16 & 347219.24 & 21701.20 & 7 \\
\hline & 21 & 229 & 3711 & 100 & 21 & 974483.48 & 46403.98 & 4 \\
\hline & 21 & 248 & 25 & 4138 & 21 & 131779.75 & 6275.23 & 9 \\
\hline 119 & 38 & 1673 & 11 & 1466 & 11 & 27613.61 & 2510.33 & 10 \\
\hline 146 & 11 & 1052 & 68 & 2338 & 11 & 45107.97 & 4100.72 & 9 \\
\hline \multirow[t]{2}{*}{157} & 13 & 1486 & 3 & 283 & 3 & 10870.18 & 3623.39 & 10 \\
\hline & 13 & 1487 & 3 & 100 & 3 & 47438.73 & 15812.91 & 8 \\
\hline 163 & 11 & 855 & 82 & 100 & 11 & 392962.88 & 35723.90 & 5 \\
\hline
\end{tabular}

a $\mathrm{WWTP}=$ wastewater treatment plants; $\mathrm{SRF}=$ Short Rotation Forestry; NPV = Net Present Value; PBP= Payback Period; Id = identification number; ha = hectare; $\mathrm{m}=$ meter

method (Chen and Hwang, 1992). This method is a sound and wellestablished tool to convert cardinal values to quality attributes, as it provides the mathematical representation of a linguistic term. Assuming a moderate risk-averse behaviour of professionals, as it results from a direct survey, we have considered the areas with values within the $0-0.77$ range as unsuitable and those within the $0.77-1$ range as suitable.

The reclassification of maps has led to identify only suitable soils with surface areas of 258,512 ha and 394 ha, respectively, for poplar and willow. Given the small area regarding willow, only the poplar suitability map was included in the spatial analysis model.

According to the calculation of the IWR of that crop, it emerged that large volumes of wastewater were required to meet irrigation requirements, up to even $19,000 \mathrm{~m}^{3} /$ ha for the second growing season. The Italian legislation on wastewater reuse does not impose any limitation on the volumes that may be supplied to crops, provided that crop irrigation requirements are not exceeded. Considering that for a vegetation filter system implemented in Sweden, up to $4000 \mathrm{~mm} /$ ha equal to $40,000 \mathrm{~m}^{3} / \mathrm{h}$ (Dimitriou and Aronsson, 2007) have been applied for the growing season, it results that the water volumes estimated in this study may be considered as being acceptable to meet the high evapotranspiration rates estimated for the crop. It was decided, however, to exclude from the analysis the soils falling within nitrate-vulnerable zones, for which more detailed analyses would be required. It results that the soils potentially suitable for vegetation filter systems are further reduced to 158,884 ha.
The determination of the potential irrigable service area has led to some considerations on WWTPs. In the region there are mostly small and medium-sized plants, with monthly average flow rates of about $25,700 \mathrm{~m}^{3}$. Looking at the curve of PBP (Fig. 4) calculated for a theoretical SRF plantation considering a $100 \mathrm{~m}$ distance (optimal siting) from the WWTP and regional mean values for IWR, the productivity and the land benefit derived from the crop concerned, it is deduced that to have an average payback time less than half of the plant lifetime ( $<6$ years), the area planted with SRF should cover at least 10 ha.

The distance of the vegetation filter from the WWTP is the most influential factor on the economic feasibility of these systems, given the high investment cost of the water conveyance pipe. With greater distances, increasing surface areas are necessary to have an economic return in the short period. As is shown in the Fig. 5, shifting from a distance of 100 to $3000 \mathrm{~m}$, areas should be five times greater to have a payback period less than 6 years.

In the spatial analysis, he plants with an potential irrigable service area lower than 10 ha were excluded, so that only 37 treatment facilities potentially useful for fertigation were identified. Based on these plants, the raster of areas of influence and distances was built. This was useful to identify the SRF soils sited downstream of WWTPs that covered 34,282 ha and were grouped by contiguity criterion through the function group (see Table 3 ).

Based on the final result of the spatial analysis model, which has supplied for each SRF soil information on the associated treatment facility, its distance from it and the mean values of productivity 


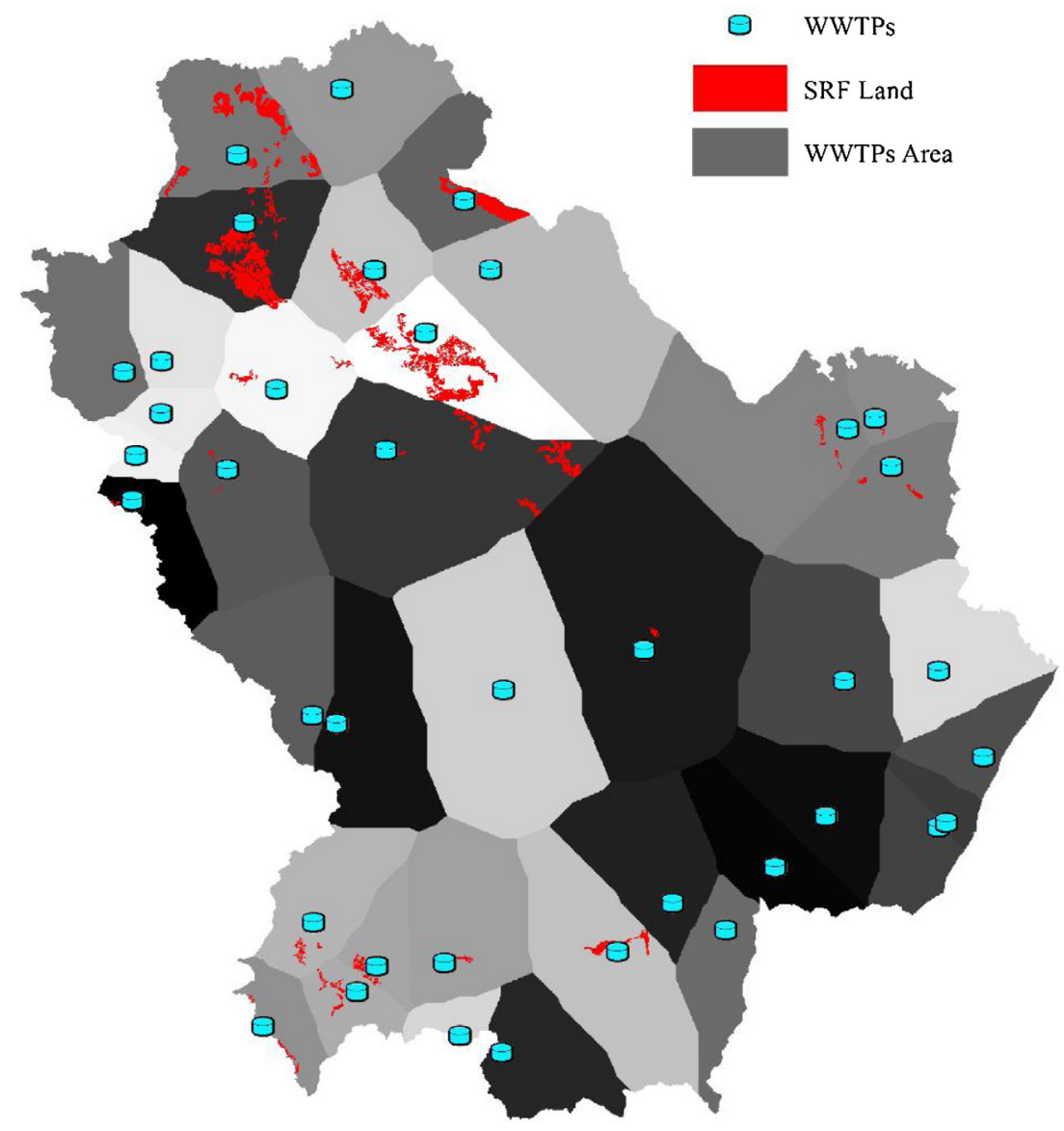

Fig. 6. Geographical location of SRF areas with positive NPV.

and land benefit, cost effectiveness indicators were calculated (see Section 3.4).

In many cases, the SRF areas identified for each treatment plant for the supply of fertigation water, were greater than the actual potential irrigable service areaof the treatment plant.

In case of areas exceeding the potential irrigable service area of WWTPs, the analysis was conducted only on the hectares that may be actually fertigated (e.g., on an area of 150 ha suitable for SRF the analysis was limited only to the 70 ha of potential irrigable service area of the WWTP, namely those with the highest cost effectiveness of the investment).

Results indicate 85 SRF areas with positive NPV falling within the areas of 25 treatment plants (Table 6). As a consequence, about 60 SRF areas are excluded, based on cost effectiveness criteria.

The choice of the areas where to direct investments depends both on NPV and on the needs of investors and their willingness to accept a longer payback period of the investment in order to have a higher economic benefit.

According to these choices, the spatial analysis model allows for quick identification of the areas that may be chosen for the investment, since they are geo-referenced (Fig. 6).

\section{Conclusion}

The use of endogenous resources looks more and more as a crucial process in the energy strategy of countries. This is even more important for those countries, including Italy, largely dependent on foreign countries for their energy requirements.

The recent orientations in development programs at the national and European level indicate well-defined strategic objectives, targeted both to fulfill the obligations undertaken in compliance with Kyoto Protocol and to ensure a greater geopolitical security, thus reducing progressively the dependence on imports. This would result in social and ecological advantages, through the reduction of harmful gas emissions, as well as economic benefits, by increasing the share of national energy needs met by the domestic production and favouring the setting up of local micro-districts that involve business growth and employment in rural areas. On the latter, it is noteworthy to consider that Italy's energy imports that account for $94 \%$ of its consumption cost as a whole about 62 billion euros per year (Ministero Sviluppo Economico, 2013). On these bases, the National Energy Strategy identifies four key objectives, namely (a) the reduction of differences in energy cost compared to the rest of Europe; (b) the achievement of environmental and decarbonization objectives set out by the EU through the $2020 \mathrm{cli}-$ mate and energy package; (c) greater food security associated with a progressive reduction of foreign dependence and (d) favouring the economic sectors connected with renewable energies.

Renewable energies are the tool to reduce harmful gas emissions, on one hand, and get economic benefits, on the other. The unique condition emerging in the implementation of a renewable strategy is that development should be widespread across the territory, as renewables are low energy sources.

The production of energy biomass on agricultural soils (SRF) provides undeniable environmental and economic benefits for society and farmers and is therefore encouraged by governments. There are, however, limitations related to the climate (notably to the precipitation trend), that influence the production significantly. The use of adequately treated wastewater is a valuable tool to increase SRF production values and ensure at the same time the uptake of part of the nitrates contained in wastewater, thus reducing treatment costs. 
Despite the many experimentations conducted in central and northern Europe, which prove the huge economic and environmental benefits derived from vegetation filter systems, in Italy their use is limited. It is necessary to arrange for tools aimed to facilitate and promote their implementation. A spatial analysis model using GIS is an appropriate means to explore the ex-ante feasibility of these systems and assess their economic and financial implications and the payback time of the investment, as well as evaluating exactly their geographical location.

Based on the above considerations, the work has proposed a spatial analysis model that has enabled to assess the agronomic and economic feasibility of multifunctional SRF plantations in Mediterranean environments and, more specifically, in the Basilicata region, Italy. Through the applied model a land use suitability analysis was carried out for SRF plantations with poplars and willows, and, based on the existing WWTPs in the region, the most suitable areas for fertigation were identified. Moreover, in the geographical assessment process a further selection criterion has also been included, which concerns professionals' risk propensity. Selected areas include only those highly suitable for the above species, and thus, likely to be successful (with values ranging between 0.77 and 1 ), thus reducing greatly the uncertainty of the investment.

According to the geographical location and the volume of treated wastewater of the existing WWTPs in the region, it results that the distance of soils from WWTPs is the discrimination factor for feasibility. Out of the 163 existing WWTPs at least 25 can fertigate 864 ha of SRF. This proves that the region has high bioenergy development potentials with undeniable economic advantages, including a large availability of sites with net benefits up to $50,876.43 € /$ ha and payback periods between 3 and 10 years.

\section{References}

AA.VV., 2012 Tariffa unificata di riferimento dei prezzi per l'esecuzione delle opere pubbliche. Ed. Regione Basilicata, Potenza, Italy.

Aronsson, P., 2000. Nitrogen retention in vegetation filters of short-rotation willow coppice. Doctoral thesis, Department of short rotation forestry, Swedish University of Agricultural Sciences, Uppsala, Sweden.

Banca d'Italia, 2013. Supplementi al bollettino Statistico. Indicatori monetari e finanziari. Anno XXIII - 13 novembre 2013. http://www.bancaditalia.it/ statistiche/stat_mon_cred_fin/banc_fin/pimemf/2013/sb60_13/suppl_60_13.pdf (accessed 05.12.13.).

Barbera, A.C., Milani, M., Bellomia, L., Castiglione, V., Toscano, A., Cavallaro, V., 2009. Effects of wastewater and different fertilization on Sorghum (Sorghum bicolor (L.) Moench) biomass production in mediterranean environment. In: Proceedings of 17th European Biomass Conference \& Exhibition from Research to Industry and Markets, 28 June-3 July, CCH-Congress Center, Hamburg, Germany.

Barredo, J.I., 1996. Sistemas de informacion geografica y evaluacion multicriterio en la ordenacion del territorio. Ra-Ma, Madrid, Spain.

Beedasy, J., Whyatt, D., 1999. Diverting the tourists: aspatial decision support system for tourism planning on a developing island. J. Appl. Earth Obse. Geoinf. $3(4), 163-174$.

Bergante, S., Facciotto, G., 2006. Impianti annuali, biennali, quinquennali. Produttività e costi in alcune realtà del Nord Italia. Swerwood 128, 25-30.

Bergante, S., Rossso, L., Facciotto, G., 2013. Produttività di cloni di pioppo e salice da biomassa in Calabria. In: IX Congresso Nazionale SISEF 'Multifunzionalità degli Ecosistemi Forestali Montani: Sfide e Opportunità per la Ricerca e lo Sviluppo' (Tonon G. Ventura M. Bucci G. eds) Bolzano, 16-19 sett. 2013. Posters - Riassunti. c9.12.96 \#227 p.109.

Berndes, G., Borjesson, P., Ostwald, M., Palm, M., 2008. Multifunctional biomass production systems - an overview with presentation of specific applications in India and Sweden. Biofuels Bioprod. Biorefin. 2 (1), 16-25.

Bernetti, I., Fagarazzi, C., Fratini, R., 2004. A methodology to anaylse the potential development of biomass-energy sector: an application in Tuscany. Forest Policy Econ. 6 (3-4), 415-432.

Bernetti, I., Ciampi, C., Fagarazzi, C., Sacchelli, S., 2011. The evaluation of forest crop damages due to climate change. An application of Dempster-Shafer method. J. Forest Econ. 17 (3), 285-297.

BIOPROS, 2008. Short Rotation Plantations: Guidelines for efficient biomass production with the safe application of wastewater and sewage sludge. http:// www.susana.org/docs_ccbk/susana_download/2-1790-biopros-d20guidelines-english.pdf (accessed 10.04.14.)
Börjesson, P., Berndes, G., 2006. The prospects for willow plantations for wastewater treatment in Sweden. Biomass Bioenergy 30 (5), 428-438.

Carlander, A., Stenström, T.A., 2001. Irrigation with pretreated wastewater on short rotation willow coppice-a sanitary study in Sweden. In: International Ecological Engineering Conference, Christchurch, New Zealand, 25-29 November.

Chen, S.J., Hwang, C.L., 1992. Fuzzy Multiple Attribute Decision Making: Methods and Applications. Springer-Vergal, Berlin, Germany.

Ciccarrella, F., Carbone, F., 2006. Valutazione finanziaria e sociale della conversione dei cedui castanili in castagneti da frutto, in ATTI DEL XLIII CONVEGNO DI STUDI: Agricolture e mercati in transizione, SIDEA, Assisi, Italy, pp. 483-504.

Cienciala, E., Lindroth, A., 1995. Gas-exchange and sap flow measurements of Salix viminalis trees in short-rotation forest- II. Diurnal and seasonal variations of stomatal response and water use efficiency. Trees 9 (5), 295-301.

Cozzi, M., Di Napoli, F., Viccaro, M., Romano, S., 2013. Use of forest residues for building forest biomass supply chains: technical and economic analysis of the production process. Forests 4 (4), 1121-1140.

Cozzi, M., Di Napoli, F., Viccaro, M., Fagarazzi, C., Romano, S., 2014. Ordered Weight Averaging multicriteria procedure and cost-effectiveness analysis for Short Rotation Forestry siting in the Basilicata Region, Italy. Int. J. Global Energy Issues 37 (5-6), 282-303.

de Wit, C.T., 1958. Transpiration and crop yields. Institute of Biological and Chemical Research on Field Crops and Herbage, No. 64.6, Wageningen, The Netherlands.

Dimitriou, I., Aronsson, P., 2007. Swedish experiences from wastewater irrigation on large-scale Short-Rotation Willow Coppice plantations. In: Environmental Applications of Poplar and Willow, Working Party 6 Workshop meeting, Montreal, Canada. http://www.fao.org/forestry/13725 0428edab0d09d737ab2189f7293277054.pdf (accessed 10.04.14.).

Dimitroiu, I., Aronsson, P., 2011. Wastewater and sewage sludge application to willows and poplars grown in lysimeters - plant response and treatment efficiency. Biomass Bioenergy 35 (1), 161-170.

Dimitriou, I., Rosenqvist, H., 2011. Sewage sludge and wastewater fertilization of Short Rotation Coppice (SRC) for increased bioenergy production - biological and economic potential. Biomass Bioenergy 35 (2), 835-842.

Dornburg, V., Faaij, A., Verweij, P., Langeveld, H., van de Ven, G., Wester, F., van Keulen, H., van Diepen, K., Meeusen, M., Banse, M., Ros, J., van Vuuren, D., van den Born, G.J., van Oorschot, M., Smout, F., van Vliet, J., Aiking, H., Londo, M., Mozaffarian, H., Smekens, K., Lysen, E., van Egmond, S., 2008. Assessment of global biomass potentials and their links to food, water, biodiversity, energy demand and economy. WAB 500,102 012, The Netherlands Environmental Assessment Agency, Bilthoven, The Netherlands.

Dornburg, V., van Vuuren, D., van de Ven, G., Langeveld, H., Meeusen, M., Banse, M., van Oorschot, M., Ros, J., van den Born, G.J., Aiking, H., Londo, M., Mozaffarian, H., Verweij, P., Lysen, E., Faaij, A., 2010. Bioenergy revisited: key factors in global potentials of bioenergy. Energy Environ. Sci. 3 (3), 258-267.

EEA, 2013. EU bioenergy potential from a resource-efficiency perspective. European Environment Agency, KongensNytorv 6, 105 0Copenhagen K Denmark.

ENAMA, 2008. Studio Progetto Biomasse ENAMA, parte 1, capitolo 1. Roma, Italia.

ENEA, 2006. Sistemi Informativi Geografici. Un percorso attraverso concetti e nozioni fondamentali per addentrarsi nel vasto mondo della Scienza della Informazione Geografica. Roma, Italia.

Ericsson, K., Rosenqvist, H., Nilsson, L.J., 2009. Energy crop production costs in the EU. Biomass Bioenergy 33 (11), 1577-1586.

ESRI, 2001. ArcGIS Spatial Analyst: Advanced GIS Spatial Analysis Using Raster and Vector Data. An ESRI White Paper. Redlands, CA, USA.

European Commission, 2012. Summary Report. 3rd European Water Conference, Brussels, 24-25 May, 2012. http://waterblueprint2012.eu (accessed 09.04.14.).

Facciotto, G., Bergante, S., Lacaria, S., 2012. Production of poplar and willow clones for biomass in Italy. In: 'Improving Lives with Poplars and Willows' Abstracts of submitted papers. 24th Session of the International Poplar Commission, Dehradun, India, 30 October-2 November 2012. Working Paper IPC/11 FAO, Rome, Italy, p. 76

FAO, 1986. Irrigation Water Management. Training Manual No. 3. Food and Agriculture Organisation, Rome, Italy.

FAO, 1998. Crop Evapotranspiration: Guidelines for Computing Crop Water Requirements. Irrigation and Drainage Paper 56. Food and Agriculture Organisation, Rome, Italy.

FAO, 2010. The wealth of waste: The economics of wastewater use in agriculture. FAO Water Report, 35. Rome, Italy.

Fiala, M., 2012. Energie da biomasse agricole. Produzione e utilizzo, Maggioli editori, Rimini, Italy.

F.I.M.A.V., 2012. Tariffe delle lavorazioni agricole per conto terzi 2012. Verona, Italia.

Fischer, M., Trnka, M., Kučera, J., Fajman, M., Žalud, Z., 2011. Biomass productivity and water use relation in short rotation poplar coppice (Populusnigra $\mathrm{X} P$. maximowiczii) in the conditions of Czech Moravian Highlands. Acta Universitatis Agriculturaeet Silviculturae Mendelianae Brunensis 59 (6), 141-152.

Forrester, D.I., Theiveyanathan, S., Collopy, J., Marcar, N.E., 2010. Enhanced water use efficiency in a mixed Eucalyptus globulus and Acacia mearnsii plantation. For. Ecol. Manage. 259 (9), 1761-1770.

Guidi, W., Piccioni, E., Bonari, E., 2008. Evapotranspiration and crop coefficient of poplar and willow short-rotation coppice used as vegetation filter. Bioresour. Technol. 99 (11), 4832-4840. 
Hasselgren, H., 2003. Use and treatment of municipal waste products in willow biomass plantations. Results from field experiments with wastewater, sewage sludge and landfill leachate. In: Licentiate Thesis, Report No. 3242. Department of Water Resources Engineering, Lund Institute of Technology, Lund University.

Heywood, I., Oliver, J., Tomlinson, S., 1995. Building an exploratory multicriteria modelling environment for spatial decision support. In: Fisher, P. (Ed.), Innovations in GIS, vol. 2. Taylor \& Francis, London, UK, pp. 127-136.

Holm, B., Heinsoo, K., 2013. Municipal wastewater application to Short Rotation Coppice of willows - treatment efficiency and clone response in Estonian case study. Biomass Bioenergy 57, 126-135.

Hoogwijk, M., Faaij, A., van den Broek, R., Berndes, G., Gielen, D., Turkenburg, W., 2003. Exploration of the ranges of the global potential of biomass for energy. Biomass Bioenergy 25 (2), 119-133.

IEA Bioenergy, 2011. Recycling of sludge and wastewater to Short Rotation Coppice (SRC) in Europe - biological and economic potential. http:/ ieabioenergytask43.org/wp-content/uploads/2013/09/IEA_Bioenergy_Task43. PR2011-04.pdf (accessed 10.04.14.).

IPCC, 2011. Special Report on Renewable Energy Sources and Climate Change Mitigation. Cambridge University Press, United Kingdom and New York, NY, USA.

Jankowski, P., 1995. Integrating geographical information systems and multiple criteria decision making methods. Int. J. Geog. Inf. Syst. 9 (3), 251-273.

Linderson, M.L., Iritz, Z., Lindroth, A., 2007. The effect of water availability on stand-level productivity, transpiration, water use efficiency and radiation use efficiency of field-grown willow clones. Biomass Bioenergy 31 (7), 460-468.

Lindroth, A., Verwijsta, T., Halldin, S., 1994. Water-use efficiency of willow: variation with season, humidity and biomass allocation. J. Hydrol. 156 (1-4), $1-19$.

Lopez, A., Pollice, A., Lonigro, A., Masi, S., Palese, A.M., Cirelli, G.L., Toscano, A., Passino, R., 2006. Agricultural wastewater reuse in southern Italy. Desalination 187 (1-3), 323-334.

Malczewski, J., 2004. GIS-based land-use suitability analysis: a critical overview. Progress Plann. 62 (1), 3-65.

Malczewski, J., 2006. Ordered weighted averaging with fuzzy quantifiers: GIS-based multicriteria evaluation for land-use suitability analysis. Int. J. Appl. Earth Obs. Geoinf. 8 (4), 270-277.

Masi, S., Caniani, D., Mancini, I.M., Trulli, E., Lavinia, C., 2008. Rimozione selettiva di sostanza organicada acque reflue attraverso uno schema a fanghi attivi modificato: modellazione e valutazioneeconomica. In: X International Symposium on Sanitary and Environmental Engineering SIDISA.08, Firenze, Italy.

Ministero Sviluppo Economico, 2013. Strategia Energetica Nazionale: per un'energia più competitiva e sostenibile. http://www.sviluppoeconomico.gov.
it/images/stories/normativa/20130314_Strategia_Energetica_Nazionale.pdf (accessed 10.04.14.).

Pistocchi, C., Guidi, W., Piccioni, E., Bonari, E., 2009. Water requirements of poplar and willow vegetation filters grown in lysimeter under Mediterranean conditions: results of the second rotation. Desalination 246 (1-3), 137-146.

Romano, S., Cozzi, M., 2006. Il governo del territorio e la conservazione delle risorse: l'uso dei modelli geografici multicriteriali per la valutazione del rischio socio economico e ambientale degli incendi boschivi. Rivista di Economia Agraria 61 (3), 365-400.

Romano, S., Cozzi, M., 2008. Valutazione delle trasformazioni del suolo e delle dinamiche in atto mediante analisi territoriale e metriche statistiche: il caso dell'hinterland potentino, Basilicata. Agribusiness Paesaggio Ambiente 11 (2), 98-108.

Romano, S., Cozzi, M., Viccaro, M., Di Napoli, F., 2013a. The green economy for sustainable development: a spatial multi-criteria analysis-ordered weighted averaging approach in the siting process for short rotation forestry in the Basilicata Region, Italy. Ital. J. Agron. 8 (3), 158-167.

Romano, S., Cozzi, M., Di Napoli, F., Viccaro, M., 2013b. Building agro-energy supply chains in the Basilicata region: technical and economic evaluation of interchangeability between fossil and renewable energy sources. Energies 6 (10), 5259-5282.

Rosenqvist, H., Dawson, M., 2005a. Economics of willow growing in Northern Ireland. Biomass Bioenergy 28 (1), 7-14.

Rosenqvist, H., Dawson, M., 2005b. Economics of using wastewater irrigation of willow in Northern Ireland. Biomass Bioenergy 29 (2), 83-92.

Saaty, T.L., 1980. The Analytic Hierarchy Process. McGraw-Hill, New York, NY, USA

Salvati, R., Chirici, G., Corona, P., 2007. Modello di valutazione dell'attitudine fisica del territorio per la realizzazione di impianti cedui da biomassa in Italia. L'Italia Forestale E Montana 5/6, 399-410.

Spinelli, R., Nati, C., Magagnotti, N., 2006. SRF di pioppo. Macchine e sistemi per la raccolta. Sherwood $128,56-59$.

Styles, D., Jones, M., 2007. Energy crops in Ireland: quantifying the potential life-cycle greenhouse gas reductions of energy-crop electricity. Biomass Bioenergy 31 (11-12), 759-772.

USDA, 1993. Irrigation Water Requirements, in National Engineering Handbook, Part 623 (ed.). United States Department of Agriculture Soil Conservation Service (USDA), Washington DC, USA.

Yager, R.R., 1996. Quantifier guided aggregation using OWA operators. Int. J. Intell. Syst. $11(1), 49-73$.

Zadeh, L.A., 1965. Fuzzy sets. Inf. Control 8 (3), 338-353. 